\title{
The Development of TPSM for Future Mathematics Candidates in SQU
}

\author{
Reda Abu-Elwan ${ }^{1 *}$
}

\author{
${ }^{1}$ Sultan Qaboos University, Muscat, OMAN \\ *CORRESPONDENCE: $\square$ abuelwan@squ.edu.om
}

\begin{abstract}
Mathematics Teacher Preparation Programs increasingly include a focus on the use of technology for teaching school mathematics. A key feature in this approach to prepare teachers to teach mathematics with technology is to integrally develop teachers' TPSM. Teachers need to understand that critical instructional decisions they make are grounded in their understandings of each domain (technology, pedagogy, and School Mathematics) and influenced by their beliefs and conceptions. The main professional course in (SQU: Sultan Qaboos University) mathematics teachers program focus on the potential integration of three domains TPSM to prepare new teachers.
\end{abstract}

Keywords: teacher education, TPSM framework, mathematics teacher accreditation

\section{INTRODUCTION}

Based on the accreditation of Mathematics Education Program in SQU, Technology uses in mathematics courses and educational professional courses become a main component in all core courses program, thus training and applied mathematics technology for future candidates' teachers is essential for them. Part of that work is to enhance teaching skills by using facilitated technology skills of candidates.

As the role of the teacher in today's society demands mastery of pedagogy, content knowledge, and understandings of learners of all ages and their social milieu become a needed for educational society in Oman.

The stated outcome objectives of the undergraduate BA in Mathematics Education program call for students to display a sound and up-to-date knowledge of mathematical sciences, display a sound and up-todate knowledge of the teaching and learning strategies, display a sound and up-to-date knowledge of using technology in mathematics teaching.

Mathematics teachers preparation program provide candidates with a system of experiences and activities designed to help students acquire competence in the application of technology to the teaching of mathematics, by complementing the general technology requirement for all teacher candidates with additional technology course work specific to the teaching of mathematics.

Historically, In the SQU professional education courses, technology integrated across courses beginning with "basic skills," such as word processing, data base development, etc. and then extending into applications of technology and then to the integration of technology into all areas of curriculum and instruction including, of course, mathematics. In this study, I noticed that candidates teaching school mathematics in "Teaching Practice" course with no use of technology, as there is no integration of technology in school mathematics textbooks. I did design this project to be part of "Mathematics for Teachers I" to increase candidates skills of

Article History: Received 21 January $2019 \bullet$ Revised 18 February $2019 \bullet$ Accepted 21 February 2019

(C) 2019 by the authors; licensee Modestum Ltd., UK. Open Access terms of the Creative Commons Attribution 4.0 International License (http://creativecommons.org/licenses/by/4.0/) apply. The license permits unrestricted use, distribution, and reproduction in any medium, on the condition that users give exact credit to the original author(s) and the source, provide a link to the Creative Commons license, and indicate if they made any changes. 
designing educational modules for the integration of TPSM, so they will be able to redesign mathematics tasks and teach it using proper technology.

\section{THEORETICAL BACKGROUND}

The National Council of Teachers of Mathematics (NCTM,2000) advocates for a shift in curriculum toward a deeper study of mathematical ideas and concepts and their uses in today's world; connecting mathematics, its ideas, and its applications - away from treating mathematics as a body of isolated concepts and procedures, a shift in student learning toward more active student involvement with the understanding of mathematics; logic and mathematical evidence as verification - away from the teacher as the sole authority for right answers mathematical reasons - away from merely memorizing procedures, a shift in teaching toward classroom as stimulating learning environments in which all students are given the opportunity to reach their mathematical potential; and classrooms as mathematical communities - away from classrooms as simply a collection of individuals conjecturing, inventing and problem-solving - away from an emphasis on mechanistic answer-finding, and a shift in assessment practices toward student evaluation that is ongoing, embedded in instruction and based on a variety of sources of evidence.

The Standards for Excellence in Teaching Mathematics in Australian Schools (Australian Association of Mathematics Teachers, 2006) described excellent mathematics teachers as purposefully and responsively adopting a wide range of strategies and techniques for using information and communication technologies (ICTs) in the classroom.

Teachers' integration of technological skills into teaching and learning needs to be appraised for two main reasons. Upholding high-quality teaching standards in schools is important, as is ensuring that students are exposed to a curriculum that takes into account instructional affordances brought by novel technologies (Handal, Cavanagh, Wood, \& Petocz, 2011).

\section{Pedagogy and School Mathematics}

Pedagogical content knowledge (PCK) is the unique blending of content expertise and skill in pedagogy to create a knowledge base that allows teachers to make robust instructional decisions. Shulman (1986) defined PCK as "a second kind of content knowledge...which goes beyond knowledge of subject matter per se to the dimension of subject matter knowledge for teaching" (p. 9). Since the time of Shulman's initial work, electronic technologies have been developed at an ever-increasing rate, and it is difficult to overestimate the impact of technology on teaching and learning, particularly in the area of mathematics (Jones\& Klepsis, 2016).

To investigate teachers' knowledge for teaching with technology, Niess (2005) expanded on the concept of PCK and described the construct of technological pedagogical content knowledge (TPCK; later referred to in the literature as technology, pedagogy, and content knowledge, or TPACK) as "the integration of development of knowledge of subject matter with the development of technology and of knowledge of teaching and learning" (p. 510).

This characterization has been so useful that, in their editorial, Bull and Bell (2009) specifically suggested using TPACK as a framework for the research of technology in mathematics teacher education. Beck and Wynn (1998) described the integration of technology in teacher preparation programs through a continuum that on one end is a course separate from the teacher preparation program and on the other end where technology is integrated throughout the program. As summarized in a draft technology position statement prepared by the Technology Committee for the Association of Mathematics Teacher Educators (2005), teacher preparation programs need to focus on strengthening the candidates' teachers' knowledge of how to incorporate technology to facilitate student learning of mathematics through experiences that:

- allow teacher candidates to explore and learn mathematics using technology in ways that build confidence and understanding of the technology and mathematics;

- model appropriate uses of a variety of established and new applications of technology as tools to develop a deep understanding of mathematics in varied contexts;

- help teacher candidates make informed decisions about appropriate and effective uses of technology in the teaching and learning of mathematics; and

- Provide opportunities for teacher candidates to develop and practice teaching lessons that take advantage of the ability of technology to enrich and enhance the learning of mathematics. 
Technology can be used in a variety of ways to improve and enhance the learning of mathematics. As NCTM (2000) highlights in its standards, technology can facilitate mathematical problem solving, communication, reasoning and proof; moreover technology can provide students with opportunities to explore different representations of mathematical ideas and support them in making connections both within and outside of mathematics (NRC, 2000).

Based on the philosophy of the integration of Pedagogy and school mathematics, I do choose problem solving and reasoning skills to be part of pedagogy and school mathematics integration process; as the main objectives of mathematics education program are developing problem solving teaching skills and reasoning teaching skills; where's Problem solving is an integral part of all mathematics learning. To solve problems, students must draw upon their knowledge of the concepts and skills they have learned and apply them to a novel situation; through this process, students develop new mathematical understanding. Problem solving should not be an isolated part of the program. Rather, problem solving should involve all content areas, numbers and operations, algebra, geometry, measurement, and data analysis and probability (NCTM, 2002):

Instructional programs from kindergarten through grade 12 should enable students to:

- Build new mathematical knowledge through problem solving

- Solve problems that arise in mathematics and other contexts

- Apply and adapt a variety of appropriate strategies to solve problems, and

- Monitor and reflect on the process of problem solving.

Meanwhile, reasoning is essential to understanding mathematics. By developing ideas, exploring phenomena, justifying results, and using mathematical conjectures in all content areas at all grade levels, students will learn that mathematics makes sense. Reasoning and proof cannot simply be taught in a single unit on logic or by 'doing proofs' in geometry. Reasoning and proof should be a consistent part of students' mathematical experience in kindergarten through grade 12. Reasoning mathematically is a habit of mind, and is developed through consistent use in many contexts.

Systematic reasoning is a defining feature of mathematics. It is found in all content areas and, with different degrees of rigor, at all grade levels. Effective instructional programs should enable students to:

- Recognize reasoning and proof as fundamental aspects of mathematics,

- Make and investigate mathematical conjectures,

- Develop and evaluate mathematical arguments and proofs, and

- Select and use various types of reasoning and methods of proof.

All learning modules developed by candidates were built on these two major pedagogy skills of problem solving and reasoning.

To be prepared to teach mathematics then, teachers need an in-depth understanding of mathematics (the content), teaching and learning (the pedagogy), and technology.

Educational modules of TPSM have been built based on the following design:

This paper examines the nature of technological pedagogical school mathematics (TPSM) of candidates through a questionnaire survey study. Questionnaires have been found to be useful instruments for investigating teachers' interaction and skills with respect to the use of technology for learning and teaching.

\section{METHODOLOGY}

One purpose of the Mathematics for Teachers II course, is to provide the opportunity for pre-service candidates teachers to use specific technological resources in mathematical contexts of middle school mathematics That is, teacher candidates are presented with a task involving some mathematical problem or situation and are required to design to use and apply an appropriate piece of technology in completing the task (Learning Modules).

\section{Research Questions}

The present study was designed to characterize the TPSM of middle school mathematics teachers' candidates. More specifically, the study sought to address the following research questions: 


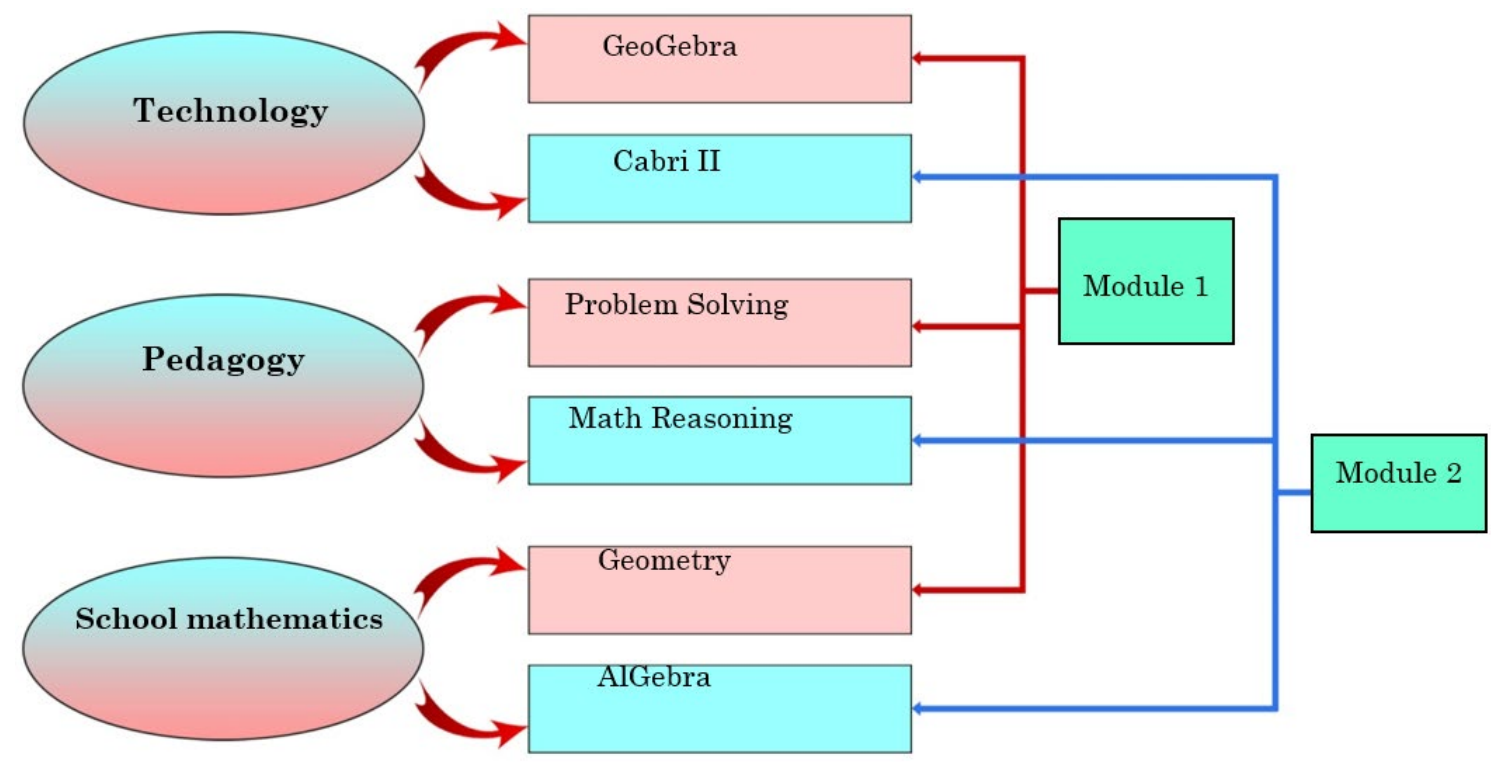

Figure 1. TPSM Framework

1. How do teaching modules factors affect the integration of geometry, reasoning and Cabri II in middle school mathematics education in the context of the TPSM model?

2. What is the candidates' interaction in the designing of TPSM teaching modules?

3. What are candidates teachers' perceived perceptions of their mathematics education program and how do they relate to their self-perceived knowledge of mathematics content, teaching methods, and technology integration?

\section{Definitions of Terms \\ Technologies}

All educational hardware and software educators can use to design, apply, and evaluate their instruction (e.g., computers, Internet, Interactive software's and calculators, etc.).

\section{TPSM framework}

The synthesized product of the three areas of knowledge technology, pedagogy (teaching and student learning), and School Mathematics (Mishra \& Koehler, 2006). Mathematics TPACK Standards: an extended framework for the work of Niess (2005), Mishra and Koehler (2006), and the National Educational Technology Standards for Teachers (ISTE 2009) focusing on mathematics education and providing guidelines about the technological pedagogical mathematics knowledge needed for teachers to accomplish high quality integration of technology in teaching mathematics (AMTE, 2009; Niess et al., 2009).

In this study, TPSM is a designing of learning modules tasks that product of the integration of specific technology for teaching geometry or algebra for middle stage students based on TPSM framework in Figure 1.

\section{Instrument}

\section{Questionnaire}

A questionnaire was developed based on candidates achieved experiences of teaching, technology, school mathematics and the National Educational Technology Standards for Teachers. This questionnaire was designed into 14 items. The questionnaire had three categories, Interactive Mathematics Technology, Mathematics concepts, and Planning and designing learning environments. The purpose of this questioner was to gather the information about the candidates' attitudes toward the designing of learning modules in TPSM. The aim of the survey is to investigate candidates' perceptions about TPSM modules design. Therefore, the questionnaire is specifically designed into 12 items. In all, 12 items are developed using a five-point Likert Scale ranging from Each item response was scored with a value of 1 for strongly disagree, 2 for disagree, 3 for neither agree or disagree, 4 for agree and 5 for strongly agree. 
INT ELECT J MATH ED

Table 1. Means and Standard deviations of candidates about TPSM modules

\begin{tabular}{llllll}
\hline$\# \quad$ Items & $N$ & Minimum & Maximum & Mean & S. Deviation \\
\hline $\begin{array}{l}\text { The integration of computing resources in the learning } \\
\text { environment encourages the improvement of the teaching- } \\
\text { learning process }\end{array}$ & 29 & 2.00 & 5.00 & 4.5172 & .82897 \\
\hline $2 \quad$ Students learn more easily when using technology & 29 & 1.00 & 5.00 & 4.5517 & .82748 \\
\hline $\begin{array}{l}\text { As a new teacher, the use of new technologies is still difficult } \\
\text { for me }\end{array}$ & 29 & 1.00 & 5.00 & 3.0690 & 1.60203 \\
\hline $\begin{array}{l}\text { Students are usually better prepared than me as a new } \\
\text { teacher in the use of technology resources. }\end{array}$ & 29 & 1.00 & 4.00 & 1.6207 & .82001 \\
\hline $5 \quad \begin{array}{l}\text { Computers, Interactive Digital Whiteboards and projectors } \\
\text { are really necessary in my mathematics classes. }\end{array}$ & 29 & 2.00 & 5.00 & 4.7241 & .64899 \\
\hline $6 \begin{array}{l}\text { I am willing to receive training in the use of any computing } \\
\text { resource to work in my mathematics classes }\end{array}$ & 29 & 4.00 & 5.00 & 4.8621 & .35093 \\
\hline $7 \begin{array}{l}\text { The teaching methodology is enhanced by the use of } \\
\text { technology resources. }\end{array}$ & 29 & 4.00 & 5.00 & 4.8966 & .30993 \\
\hline $8 \begin{array}{l}\text { Technology provides me access to new sources of knowledge } \\
\text { for my teaching of geometry }\end{array}$ & 29 & 4.00 & 5.00 & 4.4483 & .50612 \\
\hline $9 \begin{array}{l}\text { The integration of TPSM helps me to improve my teaching } \\
\text { effectiveness }\end{array}$ & 29 & 4.00 & 5.00 & 4.6207 & .49380 \\
\hline $10 \begin{array}{l}\text { The proper use of technology in problem solving encourage me } \\
\text { to provide more in problem posing }\end{array}$ & 29 & 4.00 & 5.00 & 4.8621 & .35093 \\
\hline $11 \begin{array}{l}\text { The use of mathematical reasoning using technology in } \\
\text { teaching increases my motivation as a new teacher }\end{array}$ & 29 & 4.00 & 5.00 & 4.6207 & .49380 \\
\hline $12 \begin{array}{l}\text { The use of interactive geometry increases my teaching skills } \\
\text { as a new teacher. }\end{array}$ & 29 & 3.00 & 5.00 & 4.5517 & .68589 \\
\hline
\end{tabular}

A total of 29 candidates were participated. Overall, candidates do not have much difficulty in answering the questions but on some items, phrasing is modified in the final version for easier and clearer understanding. A reliability test was done and two questions were finally removed from the pilot version in order to increase the reliability level. The data from the survey were analyzed using quantitative methods. Descriptive statistics was used to delineate how candidates view TPSM modules designing.

\section{RESULT AND DISCUSSION}

Candidates are required to design a sequence of educational modules with technology designed. A sequence of two of those Modules must integrate technology in teaching of mathematical concept. During the student teaching experience, candidates are expected to provide evidences in writing lesson reflections demonstrating their ability to teach with technology and complete their work.

There was evaluation for constructed TPSM modules of candidates based on a rubric, and each candidate's response to the questioner. Results of candidates' responses showed in Table 1.

The data in Table 1, showed that candidates generally feel that TPSM is interesting to them as it shown in item \#9 $(4.6 ; .5)$ candidates agreed that TPSM framework for learning module is effective in designing the integration of technology and mathematics and pedagogy, in addition to that there is agreement for items \# $7(4.9 ; .3) \& \# 12(4.6 ; .7) \& \# 1(4.5 ; .8)$ and \#10 $(4.8 ; .4)$. candidates showed that they are in need much more training in teaching their deigned modules, \# $6(4.8 ; .3)$ showed candidates willing to receive training in teaching under umbrella of TPSM. They enjoyed using technology in geometry and Algebra. 
Table 1. Means and Standard deviations of candidates about TPSM modules

\begin{tabular}{|c|c|c|c|c|c|c|}
\hline \# & items & $\begin{array}{l}\text { Strongly } \\
\text { Disagree }\end{array}$ & Disagree & $\begin{array}{l}\text { Neither Agree } \\
\text { or Disagree }\end{array}$ & Agree & $\begin{array}{l}\text { Strongly } \\
\text { Agree }\end{array}$ \\
\hline & & 1 & 2 & 3 & 4 & 5 \\
\hline 1 & $\begin{array}{l}\text { The integration of computing resources in the learning } \\
\text { environment encourages the improvement of the teaching- } \\
\text { learning process }\end{array}$ & & & & & \\
\hline 2 & Students learn more easily when using technology & & & & & \\
\hline 3 & $\begin{array}{l}\text { As a new teacher, the use of new technologies is still } \\
\text { difficult for me }\end{array}$ & & & & & \\
\hline 4 & $\begin{array}{l}\text { Students are usually better prepared than me as a new } \\
\text { teacher in the use of technology resources. }\end{array}$ & & & & & \\
\hline 5 & $\begin{array}{l}\text { Computers, Interactive Digital Whiteboards and } \\
\text { projectors are really necessary in my mathematics classes. }\end{array}$ & & & & & \\
\hline 6 & $\begin{array}{l}\text { I am willing to receive training in the use of any } \\
\text { computing resource to work in my mathematics classes. }\end{array}$ & & & & & \\
\hline 7 & $\begin{array}{l}\text { The teaching methodology is enhanced by the use of } \\
\text { technology resources. }\end{array}$ & & & & & \\
\hline 8 & $\begin{array}{l}\text { Technology provides me access to new sources of } \\
\text { knowledge for my teaching of geometry }\end{array}$ & & & & & \\
\hline 9 & $\begin{array}{l}\text { The integration of TPSM helps me to improve my teaching } \\
\text { effectiveness }\end{array}$ & & & & & \\
\hline 10 & $\begin{array}{l}\text { The proper use of technology in problem solving encourage } \\
\text { me to provide more in problem posing }\end{array}$ & & & & & \\
\hline 11 & $\begin{array}{l}\text { The use of mathematical reasoning using technology in } \\
\text { teaching increases my motivation as a new teacher }\end{array}$ & & & & & \\
\hline & $\begin{array}{l}\text { The use of interactive geometry increases my teaching } \\
\text { skills as a new teacher. }\end{array}$ & & & & & \\
\hline
\end{tabular}

However, interestingly, some of candidates said that "as a new teachers, the use of new technologies is still difficult to me" $(3 ; 1.6)$ and "candidates believes that their students are much better prepared than them in the use of technology" $(1.6 ; .8)$. These means with S.D. showed that candidates are in need of more training in technology uses in mathematics and be confidences to use it in teaching.

The result appears to me that candidates are doing better in designing TPSM modules, and are in need to practice of teaching much more lessons to accomplish the mastery in teaching of mathematics. However, they do not want to spend too much on theoretical aspects of the teaching strategies.

Candidates' maintaining interest toward TPSM could be due to certain activities they are engaged in during Course time, math trials and projects work for examples. However, recent emphasis of interactive mathematics programs including more mathematics problems in unfamiliar context and open-ended investigations which students are not fully used to yet may lead them to have relatively positive feeling about TPSM and their learning in mathematics. I do believe that giving candidates more opportunities to engage in a wider range of activities of TPSM in mathematics learning will further motivate students' learning enthusiasm and interest.

\section{Disclosure statement}

No potential conflict of interest was reported by the authors.

\section{Notes on contributors}

Reda Abu-Elwan - Sultan Qaboos University, Muscat, Oman.

\section{REFERENCES}

Association of Mathematics Teacher Educators' Technology Committee. (2005). Draft position statement titled Preparing Teacher to Use Technology to Enhance the Learning of Mathematics.

Australian Association of Mathematics Teachers. (2006). Standards for excellence in teaching mathematics in Australian schools. Adelaide, Australia: Author. 
Beck, J. A., \& Wynn, H. C. (1998). Technology in teacher education: Progress along the continuum. ERIC Document Reproduction No. ED 424212.

Bull, G., \& Bell, L. (2009). TPACK: A framework for the CITE Journal. Contemporary Issues in Technology and Teacher Education, 9(1). Retrieved from http://www.citejournal.org/vol9/iss 1/editorial/article1.cfm

Handal, B., Cavanagh, M., Wood, L., \& Petocz, P. (2011). Factors leading to the adoption of a learning technology: The case of graphics calculators. Australasian Journal of Educational Technology, 61(2), 70-75. https://doi.org/10.14742/ajet.974

Jones, D., Hollas, V., \& Klepsis, M. (2016). The presentation of technology for teaching and learning mathematics in textbooks: Content courses for elementary teachers. Contemporary Issues in Technology \& Teacher Education, 17(1), 53-79.

Mishra, P., \& Koehler, M. J. (in press). Designing learning from day one: A first day activity to foster design thinking about educational technology. Teacher's College Record.

Mishra, P., \& Koehler, M.J. (2006). Technological pedagogical content knowledge: A framework for teacher knowledge. Teachers College Record, 108(6), 1017-1054. https://doi.org/10.1111/j.14679620.2006.00684.x

National Council of Teachers of Mathematics. (2000). Principles and standards for school mathematics. Reston, VA: Author.

National Research Council. (2000). How people learn. Washington D. C.: National Academy Press.

Niess, M. L. (2005). Preparing teachers to teach science and mathematics with technology: Developing a technology pedagogical content knowledge. Teaching and Teacher Education, 21(5), 509-523. https://doi.org/10.1016/j.tate.2005.03.006

Shulman, L. S. (1986). Those who understand: Knowledge growth in teaching. Educational Researcher, 15(2), 4-14. https://doi.org/10.3102/0013189X015002004

\section{APPENDIXES}

\section{Appendix 1}

This questioner will measure your self-perceived knowledge of content, pedagogy, and technology. For the purpose of this study, technology term is used to refer to digital and resource such as interactive software programs, etc. Please answer all of the questions and if you are uncertain of or neutral about your response you may always select "Neither Agree or Disagree" 